\title{
PENERAPAN SETTING LEVEL OPTIMAL MENGGUNAKAN METODE TAGUCHI PADA PROSES PRODUKSI BATIK TULIS UNTUK MENINGKATKAN KUALITAS PRODUK DI SENTRA INDUSTRI BATIK TULIS KALINYAMAT WETAN KOTA TEGAL
}

\author{
Saufik Luthfianto, Siswiyanti, Ahmad Farid \\ Program Studi Teknik Industri \\ Universitas Pancasakti Tegal \\ email: saufik34@yahoo.com
}

\begin{abstract}
ABSTRAK
Penelitian ini mengambil obyek di sentra industri batik yang berlokasi di desa Kalinyamat Wetan Kota Tegal, yang merupakan kumpulan dari home industries yang bergerak pada pembuatan kain batik, baik itu batik tulis. Dari hasil survey awal sekitar 20\% produk yang mengalami cacat seperti warna yang tidak sama antara satu batik dengan batik lainnya, kualitas kain yang kurang nyaman dan kekuatan kain yang mudah robek sehingga ada beberapa batik tulis yang dikembalikan kepada pengrajin karena kualitasnya kurang bagus. Penelitian ini menggunakan rancangan eksperimental murni yang mengidentifikasi karakteristik kualitas dengan metode taguchi, terdiri 4 faktor terkendali masing-masing memiliki 2 level, Jumlah level dan faktor yang ada dapat ditentukan jumlah baris untuk matriks orthogonal array yaitu 8 sehingga orthogonal array yang sesuai adalah $L_{8}\left(2^{7}\right)$. Hasil penelitian ini adalah faktor -faktor yang berpengaruh pada hasil desain produk batik tulis Tegal adalah bahan kain batik, pewarnaan, pencelupan dan pelilinan, Setting level optimal dari tingkat kualitas hasil desain sebagai dasar peningkatan kualitas produk batik tulis Tegal adalah pada bahan kain batik menggunakan mori primissima kupu, pewarnaan dengan warna naftol, pencelupan selama 50 menit dan pelilinan dengan suhu $70^{\circ} \mathrm{C}$., dari analisis of variance mean dan SNR memberikan hasil yaitu F hitung lebih besar dari F tabel ini berarti bahwa semua faktor signifikan terhadap Ketahanan Luntur Warna terhadap Sabun, Ketahanan Luntur Warna terhadap Gosokan Kain , dan Kekuatan Tarik dan Mulur Kain, Peningkatan kualitas batik tulis tegal dari pengujian ketahanan luntur warna terhadap sabun, kekuatan tarik, dan ketahanan luntur warna terhadap gosokan kering masing-masing adalah sebesar 8\%, 5,03\% dan $17,33 \%$ dengan rata-rata peningkatan kualitas sebesar 10,12\%.
\end{abstract}

Kata Kunci: setting level optimal, kualitas

\section{PENDAHULUAN}

Penelitian ini mengambil obyek di sentra industri batik yang berlokasi di desa Kalinyamat Wetan Kota Tegal, yang merupakan kumpulan dari home industries yang bergerak pada pembuatan kain batik, baik itu batik tulis. Sampai saat ini sentra industri batik ini belum mempunyai standart kualitas produk sehingga banyak terjadi complaint dari agen atau pengecer terhadap hasil produk yang berhubungan dengan kualitas, dimana banyak produk yang mengalami cacat seperti warna yang tidak sama antara satu batik dengan batik lainnya, kualitas kain yang kurang nyaman dan kekuatan kain yang mudah robek sehingga ada beberapa batik tulis yang dikembalikan kepada pengrajin karena kualitasnya kurang bagus, terutama produk batik tulisnya. Dari hasil survey Rata-rata permintaan produk batik di Desa Kalinyamat Wetan Kota Tegal adalah 5 kodi atau sama dengan 100 Unit batik tiap bulan, sebagian besar permintaan produk batik ini adalah berupa kain batik tulis. Padahal kapasitas produksi sentra industri batik ini rata-rata 4 kodi atau sama dengan 80 unit/bulan. Sehingga disinyalir hanya sekitar $80 \%$ produk batik di desa Kalinyamat Wetan Kota Tegal yang mampu menembus pasar. Belum lagi dengan produk yang cacat atau tidak diterima atau dikembalikan oleh agen, distributor atau bahkan usernya sendiri. Penelitian ini ingin memperbaiki dan meningkatkan kualitas produk terutama pada produk utamanya yaitu kain batik tulis, sehingga produk yang dibuat lebih mempunyai kualitas yang baik di pasar serta mampu memenuhi harapan yang diinginkan konsumen produk kain batik tulis. 


\section{LANDASAN TEORI}

\section{A. Kajian Pustaka}

Pada penelitian tentang batik menurut Indrojarwo (2010) mendefinisikan desain batik dalam "Batik Fisika” Bandung Fe Institute, yang memakai pendekatan sains untuk mendesain batik melalui teknik fractal, yaitu teknik pembuatan patra atau pengulangan secara generative (tidak sama persis) seperti proses tumbuhnya ranting dan daun pada sebuah pohon. Sedangkan menurut Hasanudin (2001), dalam "Batik Pesisiran; Melacak Pengaruh Etos Dagang Santri pada Ragam Hias Batik" membahas ciri khas sentra batik di Pulau Jawa dan model pengelolaan bisnis batik, seluk-beluk peralatan membatik, dari cara pemakaian dan pemeliharaan hingga sentra produsen perlengkapan membatik tersebut. Pada penelitian Raharjo (2006) dihasilkan bahwa Batik Tulis Tengah Sawah dapat dikelompokkan menjadi dua kelompok yaitu motif geometris dan motif non geometris, banyak menciptakan motif-motif baru yang sumber idenya dari alam sekitar, majalah, buku dan kreasi sendiri. Dari kajian pustaka muncul suatu ide untuk mengimplementasikan batik tulis berdasarkan desain pada setting level optimal proses produksinya. Desain tersebut akan diaplikasikan untuk mengetahui kualitas batik tulis Tegal.

\section{B. Metode Taguchi}

Menurut Ross (1996) ada tiga tahap penting dalam perancangan proses off-line quality control, yaitu:

a. System design (primary design), Tahap ini adalah tahap yang berkaitan dengan pengembangan teknologi. Tahap ini memerlukan pengetahuan teknis yang luas dan mendalam untuk menilai pengembangan produk atau proses (tidak memerlukan perancangan eksperimen).

b. Parameter design (secondary design), Tahap perancangan parameter berkaitan dengan penekanan biaya dan peningkatkan kualitas dengan menggunakan metode perancangan eksperimen yang efektif. Hal ini termasuk penentuan nilai parameter yang kurang sensitive terhadap faktor noise dan mencari kombinasi level parameter yang dapat mengurangi faktor noise. Tahap ini adalah tahap utama dalam perancangan kokoh agar produk atau proses mempunyai kehandalan yang tinggi, walaupun material yang digunakan tidak mahal, mempunyai keragaman tinggi dan mudah rusak (aus).

c. Tolerance design (tertiary design), Tahap ini berkaitan dengan pengendalian faktorfaktor yang mempengaruhi nilai target dengan menggunakan komponen mutu tinggi dan biaya tinggi yang tidak dapat dielakkan. Setelah sistem dirancang (melalui system design) dan nilai tengah parameternya ditentukan (melalui parameter design), langkah berikutnya membuat toleransi parameter (melalui tolerance design). Faktor noise, termasuk juga parameter sistem dimasukkan dalam rancangan eksperimen untuk menentukan dampaknya pada karakteristik keluaran. Toleransi yang lebih sempit harus diberikan pada faktor noise yang mempunyai pengaruh terbesar pada karakteristik keluaran. Karena faktor noise tidak dapat dihilangkan, karakteristik kualitas dari produk tidak akan mencapai nilai target. Prinsip kekokohan berusaha untuk mengurangi kerugian dengan melakukan pengendalian faktor terhadap faktor noise, sehingga spesifikasi produk dapat diidentifikasi dan membuat karakteristik kualitas tidak sensitif terhadap noise.

Penentuan faktor-faktor yang berpengaruh dalam eksperimen beserta setting level ada beberapa hal yang harus dipertimbangkan, yaitu:

1. Factor levels, merupakan jumlah level atau atribut yang diberikan oleh faktor-faktor yang berpengaruh dalam eksperimen, baik faktor terkendali, faktor noise, faktor signal, atau faktor skala.

2. Number of factor levels, jumlah level dan setting level yang dipilih tergantung pada sejauh mana kita mengetahui proses atau produk yang akan diteliti. 
3. Range of factor levels, semakin luas jarak yang digunakan dalam eksperimen, maka kemungkinan ditemukannya efek dari faktor yang ada dalam penentuan karakteristik kualitas akan semakin baik.

4. Feasibility of factor levels, dalam pemilihan level untuk tiap faktornya perlu mempertimbangkan apakah level yang dipilih memungkinkan atau dapat dijalankan dalam membuat kombinasi eksperimen.

\section{METODOLOGI PENELITIAN}

Penelitian ini menggunakan rancangan eksperimental murni yang mengidentifikasi karakteristik kualitas dengan metode taguchi, terdiri 4 faktor terkendali masing-masing memiliki 2 level, Jumlah level dan faktor yang ada dapat ditentukan jumlah baris untuk matriks orthogonal array yaitu 8 sehingga orthogonal array yang sesuai adalah $\mathrm{L}_{8}\left(2^{7}\right)$, pada tahapan metode taguchi ini dilakukan untuk menentukan faktor-faktor berpengaruh pada levelnya yang akan dilibatkan dalam eksperimen.

\section{HASIL DAN PEMBAHASAN}

\section{A. Faktor-faktor yang diduga berpengaruh terhadap produk batik tulis, yaitu:} Identifikasi faktor-faktor yang berpengaruh terhadap kualitas desain batik tulis Tegal dapat dilihat pada tabel 1 sebagai berikut:

Tabel 1 Faktor-faktor yang berpengaruh

\begin{tabular}{|c|l|}
\hline No & \multicolumn{1}{|c|}{ Faktor yang terkendali } \\
\hline 1 & Bahan kain Batik (A) \\
\hline 2 & Pewarnaan (B) \\
\hline 3 & Pencelupan (C) \\
\hline 4 & Pelilinan (D) \\
\hline
\end{tabular}

Eksperimen yang dilakukan dalam penelitian ini menggunakan dua setting level faktor yang menunjukkan level tinggi (high), dan rendah (low). Setting level untuk faktorfaktor yang dilibatkan dalam eksperimen diuraikan sebagai berikut:

A. Variasi bahan kain batik adalah menggunakan mori primis, dan mori primissima kupu. Pemilihan kedua mori ini didasarkan pada kesetaraan harga pada kondisi actual serta diperkirakan akan terjadi peningkatan kualitas kekuatan kain.

B. Variasi pewarnaan terhadap kelunturan adalah warna rapid, warna naftol, dimana pada level lebih tinggi diperkirakan akan terjadi peningkatan kualitas pewarnaan yang tahan luntur.

C. Variasi pencelupan terhadap pewarnaan adalah 30 menit dan 50 menit dimana pada level yang tinggi diperkirakan akan terjadi peningkatan kualitas warna.

D. Variasi pelilinan atau malam terhadap pewarnaan adalah $60^{\circ}$ dan $70^{\circ}$ dimana pada level yang semakin tinggi diperkirakan akan semakin memperkuat warna sehingga warna tidak mudah hilang.

Berikut ini tabel 2 Penugasan setting level factor untuk eksperimen taguchi

Tabel 2 Penugasan Setting Level Factor

\begin{tabular}{|l|c|c|}
\hline \multicolumn{1}{|c|}{ Faktor terkendali } & Level 1 & Level 2 \\
\hline Bahan Kain Batik & mori primis & mori primissima kupu \\
\hline Pewarnaan & warna rapid & warna naftol \\
\hline Pencelupan & 30 menit & 50 menit \\
\hline Pelilinan & $60^{\circ} \mathrm{C}$ & $70^{\circ} \mathrm{C}$ \\
\hline
\end{tabular}




\section{B. Analisa Statistik terhadap Nilai Rata-rata dan SNR}

\section{Pengujian Ketahanan Luntur Warna terhadap Sabun}

Pengujian ini dimaksudkan untuk mengetahui ketahanan luntur warna terhadap pencucian sabun produk batik tulis Tegal. Data pengujian ketahanan luntur warna terhadap pencucian sabun terlihat pada tabel 3 sebagai berikut:

Tabel 3 Hasil Eksperimen Taguchi

\begin{tabular}{|c|c|c|c|c|c|c|c|c|}
\hline \multirow{2}{*}{ NO } & \multicolumn{3}{|c|}{ FAKTOR TERKENDALI } & \multicolumn{4}{|c|}{ REPLIKASI DESAIN } \\
\cline { 2 - 9 } & A & B & C & D & $\mathbf{1}$ & $\mathbf{2}$ & $\mathbf{3}$ & $\mathbf{4}$ \\
\hline 1 & 1 & 1 & 1 & 1 & 4.0 & 3.0 & 4.0 & 4.0 \\
\hline 2 & 1 & 1 & 2 & 2 & 4.0 & 4.0 & 5.0 & 4.0 \\
\hline 3 & 1 & 2 & 1 & 1 & 4.0 & 4.0 & 4.0 & 4.0 \\
\hline 4 & 1 & 2 & 2 & 2 & 4.0 & 4.0 & 4.0 & 5.0 \\
\hline 5 & 2 & 1 & 1 & 2 & 4.0 & 4.0 & 5.0 & 4.0 \\
\hline 6 & 2 & 1 & 2 & 1 & 4.0 & 5.0 & 4.0 & 4.0 \\
\hline 7 & 2 & 2 & 1 & 2 & 5.0 & 5.0 & 4.0 & 5.0 \\
\hline 8 & 2 & 2 & 2 & 1 & 5.0 & 5.0 & 5.0 & 4.0 \\
\hline
\end{tabular}

a. Uji Normalitas Data terhadap eksperimen taguchi

Tabel 4 Hasil Uji Normalitas Data

One-Sample Kolmogorov-Smirnov Test

\begin{tabular}{|c|c|c|c|c|c|}
\hline & & Rep_des_1 & Rep_des_2 & Rep_des_3 & Rep_des_4 \\
\hline \multicolumn{2}{|l|}{$\mathrm{N}$} & 8 & 8 & 8 & 8 \\
\hline \multirow[t]{2}{*}{ Normal Parameters ${ }^{a}$} & Mean & 4.25 & 4.25 & 4.38 & 4.25 \\
\hline & Std. Deviation & .463 & .707 & .518 & .463 \\
\hline \multirow[t]{3}{*}{ Most Extreme Differences } & Absolute & .455 & .263 & .391 & .455 \\
\hline & Positive & .455 & .263 & .391 & .455 \\
\hline & Negative & -.295 & -.237 & -.261 & -.295 \\
\hline Kolmogorov-Smirnov Z & & 1.288 & .744 & 1.105 & 1.288 \\
\hline Asymp. Sig. (2-tailed) & & .072 & .637 & .174 & .072 \\
\hline 1. Test distribution is Norn & & & & & \\
\hline
\end{tabular}

Sumber : olah data SPSS 16, 2013

Berdasarkan perhitungan, didapat nilai $p$ pada seluruh aspek lebih besar daripada 0.05 ( $p>0.05$ ) dengan demikian semua data berdistribusi normal.

b. Uji Homogenitas Data terhadap eksperimen taguchi

Tabel 5 Hasil Uji Homogenitas Data

Test of Homogeneity of Variance

\begin{tabular}{|ll|r|r|r|r|}
\hline & Levene Statistic & df1 & df2 & \multicolumn{1}{c|}{ Sig. } \\
\hline Replikasi_desain & Based on Mean & .983 & 3 & 28 & .415 \\
& $\begin{array}{l}\text { Based on Median } \\
\text { Based on Median and with } \\
\quad \begin{array}{l}\text { adjusted df } \\
\text { Based on trimmed mean }\end{array}\end{array}$ & .467 & 3 & 28 & .708 \\
& & .467 & 3 & 27.536 & .708 \\
& 1.124 & 3 & 28 & .356 \\
\hline
\end{tabular}

Sumber : olah data SPSS 16, 2013 
Berdasarkan perhitungan, didapat nilai $p$ lebih besar daripada $0.05(p>0.05$ ) dengan demikian data hasil eksperiment taguchi memiliki varian yang homogen. Setelah diketahui bahwa hasil eksperiment taguchi memiliki syarat bahwa data tersebut adalah normal dan homogen, maka langkah selanjutnya adalah menghitung berdasarkan langkah-langkah eksperiment taguchi:

\section{c. Menghitung nilai rata-rata dan SNR pada eksperimen taguchi}

Tabel 6 Tabel respon untuk nilai rata-rata Response Table for Means

\begin{tabular}{lrrrr}
\hline Level & bahan & pewarnaan & pencelupan & pelilinan \\
1 & 4,063 & 4,125 & 4,188 & 4,188 \\
2 & 4,500 & 4,438 & 4,375 & 4,375 \\
Delta & 0,438 & 0,313 & 0,188 & 0,188 \\
Rank & 1 & 2 & 3,5 & 3,5 \\
\hline
\end{tabular}

Sumber: olah data minitab 14, 2013

Berdasarkan tabel 6 dapat dilihat bahwa faktor bahan yang mempunyai rata- rata nilai eksperimen TLW terhadap pencucian yang lebih tinggi adalah level 2, faktor pewarnaan yang mempunyai nilai eksperimen TLW terhadap pencucian yang lebih tinggi adalah level 2, faktor pencelupan yang mempunyai nilai eksperimen TLW terhadap pencucian tertinggi adalah level 2, sedangkan faktor pelilinan yang tertinggi adalah level 2. Dari tabel respon rata-rata diatas dapat juga dilihat pada gambar grafik untuk respon rata-rata tiap level factor

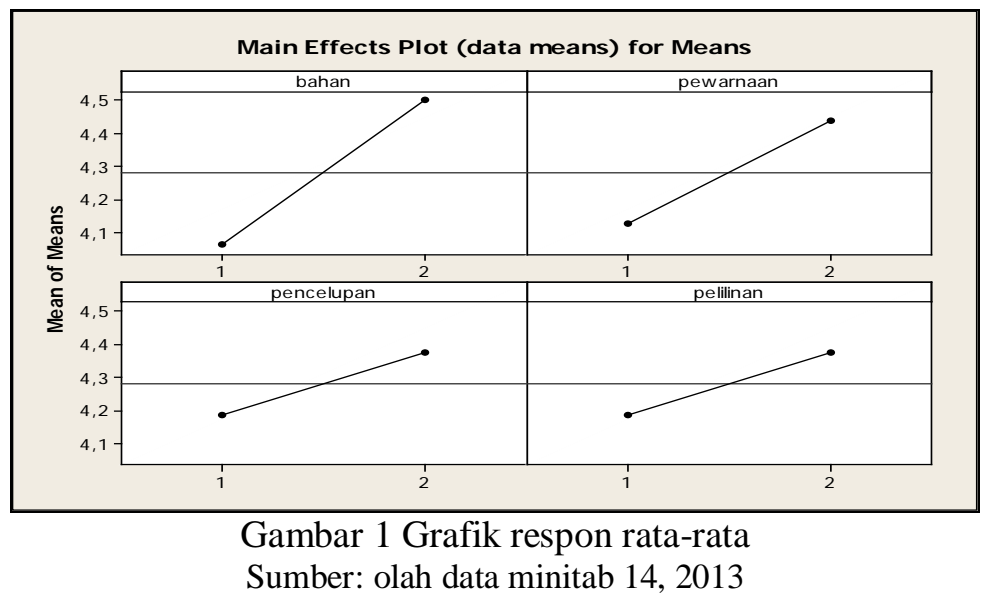

Berdasarkan gambar 1 grafik untuk respon rata-rata tiap level faktor, dapat juga dilihat bahwa faktor bahan yang mempunyai rata- rata ketahanan luntur yang lebih tinggi adalah level 2, faktor pewarnaan yang mempunyai rata-rata ketahanan luntur yang lebih tinggi adalah level 2, faktor pencelupan yang mempunyai rata-rata ketahanan luntur tertinggi adalah level 2, sedangkan faktor pelilinan yang tertinggi adalah level 2.

Sedangkan taguchi dengan menggunakan analysis of signal to noise ratio untuk mencari faktor-faktor yang memiliki kontribusi pada pengurangan variansi suatu karakteristik kualitas (variabel respon). Karakteristik kualitas yang digunakan adalah TLW terhadap pencucian, dimana semakin tinggi nilainya semakin baik sehingga SNR yang digunakan adalah larger the better. Dapat ditunjukkan pada tabel dibawah ini. 
Tabel 7 Tabel Respon untuk nilai SNR

Response Table for Signal to Noise Ratios

Larger is better

\begin{tabular}{lrrrr}
\hline Level & bahan & pewarnaan & pencelupan & pelilinan \\
1 & 12,05 & 12,16 & 12,29 & 12,29 \\
2 & 12,93 & 12,83 & 12,69 & 12,69 \\
Delta & 0,88 & 0,67 & 0,40 & 0,40 \\
Rank & 1 & 2 & 3,5 & 3,5 \\
\hline
\end{tabular}

Sumber: olah data minitab 14, 2013

Berdasarkan tabel 7 dapat dilihat bahwa faktor bahan yang mempunyai nilai SNR eksperimen TLW terhadap pencucian yang lebih tinggi adalah level 2, faktor pewarnaan yang mempunyai nilai eksperimen TLW terhadap pencucian yang lebih tinggi adalah level 2, faktor pencelupan yang mempunyai nilai eksperimen TLW terhadap pencucian tertinggi adalah level 2, sedangkan faktor pelilinan yang tertinggi adalah level 2. Dari tabel respon rata-rata diatas dapat juga dilihat pada gambar grafik untuk respon nilai SNR tiap level faktor

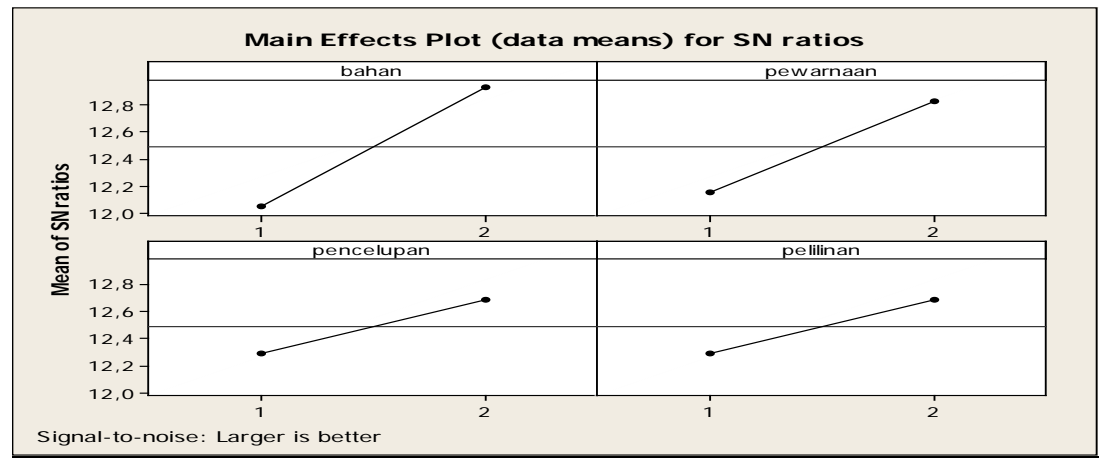

Gambar 2 Grafik untuk Respon Nilai SNR

Sumber: olah data minitab 14, 2013

Berdasarkan gambar 1 grafik untuk respon rata-rata tiap level faktor, dapat juga dilihat bahwa faktor bahan yang mempunyai rata- rata ketahanan luntur yang lebih tinggi adalah level 2, faktor pewarnaan yang mempunyai rata-rata ketahanan luntur yang lebih tinggi adalah level 2, faktor pencelupan yang mempunyai rata-rata ketahanan luntur tertinggi adalah level 2, sedangkan faktor pelilinan yang tertinggi adalah level 2.

Dari analisis statistik terhadap nilai respon rata-rata dan SNR baik dari perhitungan tabel dan grafik memberikan hasil yang sama yaitu: faktor A (bahan) yang mempunyai rata-rata ketahanan luntur yang lebih tinggi adalah level 2, faktor B (pewarnaan) yang mempunyai rata-rata ketahanan luntur yang lebih tinggi adalah level 2, faktor $\mathrm{C}$ (pencelupan) yang mempunyai rata-rata ketahanan luntur yang lebih tinggi adalah level 2, dan faktor D (pelilinan) yang mempunyai rata-rata ketahanan luntur yang lebih tinggi adalah level 2.

\section{d. Menghitung Analysis of Variance}

Analisis selanjutnya adalah menghitung Analysis of Variance (mean) dan Analysis of Variance (SNR) dari tabel respon, hasil Analysis of Variance (mean) dapat dilihat pada tabel 8 dibawah ini: 
Tabel 8 Analysis of Variance (mean)

Analysis of Variance for Means

\begin{tabular}{|c|c|c|c|c|c|c|}
\hline Source & DF & Seq SS & Adj SS & Adj MS & $F$ & $\mathrm{P}$ \\
\hline bahan & 1 & 0,38281 & $\odot, 38281$ & $\odot, 382812$ & 49,00 & 0,020 \\
\hline pewarnaan & 1 & 0,19531 & ๑, 19531 & 0,195313 & $25,0 \odot$ & $\odot, 038$ \\
\hline pencelupan & 1 & ๑, 07031 & $\odot, 07031$ & $\bullet, 070313$ & $9,0 \odot$ & $\odot, 095$ \\
\hline pelilinan & 1 & 0,07031 & $\odot, 07031$ & $\bullet, 070312$ & $9,0 \odot$ & $\odot, 095$ \\
\hline bahan*pewarnaan & 1 & 0,07031 & $\odot, 07031$ & 0,070313 & $9,0 \odot$ & $\odot, 095$ \\
\hline Residual Error & 2 & 0,01563 & $\odot, 01563$ & $\odot, 007813$ & & \\
\hline Total & 7 & 0,80469 & & & & \\
\hline
\end{tabular}

Sumber: olah data minitab 14, 2013

Berdasarkan tabel 8 maka dapat dilihat bahwa $\mathrm{F}$ hitung lebih besar dari $\mathrm{F}$ tabel, yaitu $\mathrm{F}_{\mathrm{A}}=49,00>\mathrm{F}_{\text {tabel }}=4,74 ; \mathrm{F}_{\mathrm{B}}=25,00>\mathrm{F}_{\text {tabel }}=4,74 ; \mathrm{F}_{\mathrm{C}}=9,00>\mathrm{F}_{\text {tabel }}=4,74$; dan $F_{D}=9,00>F_{\text {tabel }}=4,74$. Ini berarti semua faktor signifikan terhadap kelunturan warna pencucian sabun.

Untuk Analysis of Variance (SNR) dapat dilihat pada tabel 9 dibawah ini:

Tabel 9 Analysis of Variance (SNR)

Analysis of Variance for SN ratios

\begin{tabular}{lrlllrr}
\hline Source & DF & Seq SS & Adj SS & Adj MS & F & P \\
bahan & 1 & 1,5358 & 1,5358 & 1,53581 & 20,63 & 0,045 \\
pewarnaan & 1 & 0,9018 & 0,9018 & 0,90184 & 12,12 & 0,074 \\
pencelupan & 1 & 0,3163 & 0,3163 & 0,31634 & 4,95 & 0,175 \\
pelilinan & 1 & 0,3163 & 0,3163 & 0,31634 & 4,95 & 0,175 \\
bahan*pewarnaan & 1 & 0,1632 & 0,1632 & 0,16322 & 2,19 & 0,277 \\
Residual Error & 2 & 0,1489 & 0,1489 & 0,07443 & & \\
Total & 7 & 3,3824 & & & &
\end{tabular}

Sumber: olah data minitab 14, 2013

Berdasarkan tabel 9 maka dapat dilihat bahwa $\mathrm{F}$ hitung lebih besar dari $\mathrm{F}$ tabel, yaitu $\mathrm{F}_{\mathrm{A}}=20,00>\mathrm{F}_{\text {tabel }}=4,74 ; \mathrm{F}_{\mathrm{B}}=12,00>\mathrm{F}_{\text {tabel }}=4,74 ; \mathrm{F}_{\mathrm{C}}=4,95>\mathrm{F}_{\text {tabel }}=4,74$; dan $F_{D}=4,95>F$ tabel $=4,74$. Ini berarti semua faktor signifikan terhadap kelunturan warna pencucian sabun.

Dari Analysis of Variance mean dan SNR memberikan hasil yang sama yaitu F hitung lebih besar dari $\mathrm{F}$ tabel ini berarti bahwa semua faktor signifikan terhadap kelunturan warna pencucian sabun.

\section{Pengujian Ketahanan Luntur Warna terhadap Gosokan Kain (kering)}

Pengujian ini dimaksudkan untuk mengetahui ketahanan luntur warna terhadap gosokan kain produk batik tulis Tegal. Data pengujian ketahanan luntur warna terhadap gosokan kain terlihat pada tebel 10 sebagai berikut:

Tabel 10 Hasil Eksperimen Taguchi

\begin{tabular}{|c|c|c|c|c|c|c|c|c|}
\hline \multirow{2}{*}{ NO } & \multicolumn{4}{|c|}{ FAKTOR TERKENDALI } & \multicolumn{4}{c|}{ REPLIKASI DESAIN } \\
\cline { 2 - 9 } & A & B & C & D & $\mathbf{1}$ & $\mathbf{2}$ & $\mathbf{3}$ & $\mathbf{4}$ \\
\hline 1 & 1 & 1 & 1 & 1 & 4.0 & 3.0 & 3.0 & 4.0 \\
\hline 2 & 1 & 1 & 2 & 2 & 4.0 & 4.0 & 4.0 & 4.0 \\
\hline 3 & 1 & 2 & 1 & 1 & 4.0 & 4.0 & 4.0 & 4.0 \\
\hline 4 & 1 & 2 & 2 & 2 & 4.0 & 4.0 & 3.0 & 4.0 \\
\hline 5 & 2 & 1 & 1 & 2 & 5.0 & 4.0 & 4.0 & 5.0 \\
\hline 6 & 2 & 1 & 2 & 1 & 4.0 & 5.0 & 4.0 & 5.0 \\
\hline 7 & 2 & 2 & 1 & 2 & 5.0 & 4.0 & 3.0 & 4.0 \\
\hline 8 & 2 & 2 & 2 & 1 & 5.0 & 5.0 & 5.0 & 5.0 \\
\hline
\end{tabular}




\section{a. Uji Normalitas Data terhadap eksperimen taguchi}

Tabel 11 Hasil Uji Normalitas Data

One-Sample Kolmogorov-Smirnov Test

\begin{tabular}{|c|c|c|c|c|c|}
\hline & & $\begin{array}{c}\text { Rep_desain_ } \\
1\end{array}$ & $\begin{array}{c}\text { Rep_desain_ } \\
2\end{array}$ & $\begin{array}{c}\text { Rep_desain_ } \\
3\end{array}$ & Rep_desain_ \\
\hline \multicolumn{2}{|l|}{$\mathrm{N}$} & 9 & 9 & 9 & 9 \\
\hline \multirow[t]{2}{*}{ Normal Parameters ${ }^{\mathrm{a}}$} & Mean & 4.33 & 4.22 & 3.89 & 4.33 \\
\hline & Std. Deviation & .500 & .667 & .782 & .500 \\
\hline \multirow[t]{3}{*}{ Most Extreme Differences } & Absolute & .414 & .297 & .223 & .414 \\
\hline & Positive & .414 & .297 & .221 & .414 \\
\hline & Negative & -.252 & -.258 & -.223 & -.252 \\
\hline Kolmogorov-Smirnov Z & & 1.243 & .892 & .670 & 1.243 \\
\hline Asymp. Sig. (2-tailed) & & .091 & .404 & .761 & .091 \\
\hline a. Test distribution is Norm & & & & & \\
\hline
\end{tabular}

Sumber : olah data SPSS 16, 2013

Berdasarkan perhitungan, didapat nilai $p$ pada seluruh aspek lebih besar daripada 0.05 ( $\mathrm{p}>0.05$ ) dengan demikian semua data berdistribusi normal.

\section{b. Uji Homogenitas Data terhadap eksperimen taguchi}

Tabel 12 Hasil Uji Homogenitas Data

Test of Homogeneity of Variance

\begin{tabular}{|rl|r|r|r|r|}
\hline & Levene Statistic & df1 & df2 & \multicolumn{1}{c|}{ Sig. } \\
\hline Rep_desain & Based on Mean & .438 & 3 & 32 & .727 \\
& Based on Median & .386 & 3 & 32 & .764 \\
Based on Median and with & & & \\
$\quad$ adjusted df & .386 & 3 & 31.912 & .764 \\
& Based on trimmed mean & .515 & 3 & 32 & .675 \\
\hline
\end{tabular}

Sumber : olah data SPSS 16, 2013

Berdasarkan perhitungan, didapat nilai $p$ lebih besar daripada 0.05 ( $p>0.05$ ) dengan demikian data hasil eksperiment taguchi memiliki varian yang homogen.

Setelah diketahui bahwa hasil eksperiment taguchi memiliki syarat bahwa data tersebut adalah normal dan homogen, maka langkah selanjutnya adalah menghitung berdasarkan langkah-langkah eksperiment taguchi:

\section{c. Menghitung nilai rata-rata dan SNR pada eksperimen taguchi}

Tabel 13 Tabel respon untuk nilai rata-rata Response Table for Means

\begin{tabular}{lrrrr}
\hline Level & bahan & pewarnaan & pencelupan & pelilinan \\
1 & 3,813 & 4,125 & $4,00 \odot$ & $4,25 \odot$ \\
2 & $4,50 \odot$ & 4,188 & 4,313 & 4,063 \\
Delta & 0,688 & 0,063 & $\odot, 313$ & $\odot, 188$ \\
Rank & 1 & 4 & 2 & 3 \\
\hline
\end{tabular}

Sumber: olah data minitab 14, 2013

Berdasarkan tabel 13 dapat dilihat bahwa faktor bahan yang mempunyai ratarata nilai eksperimen ketahanan luntur warna terhadap gosokan kain yang lebih tinggi adalah level 2, faktor pewarnaan yang mempunyai nilai eksperimen ketahanan luntur warna terhadap gosokan kain yang lebih tinggi adalah level 2, 
faktor pencelupan yang mempunyai nilai eksperimen ketahanan luntur warna terhadap gosokan kain dalah level 2, sedangkan faktor pelilinan yang tertinggi adalah level 1. Dari tabel respon rata-rata diatas dapat juga dilihat pada gambar grafik untuk respon rata-rata tiap level faktor

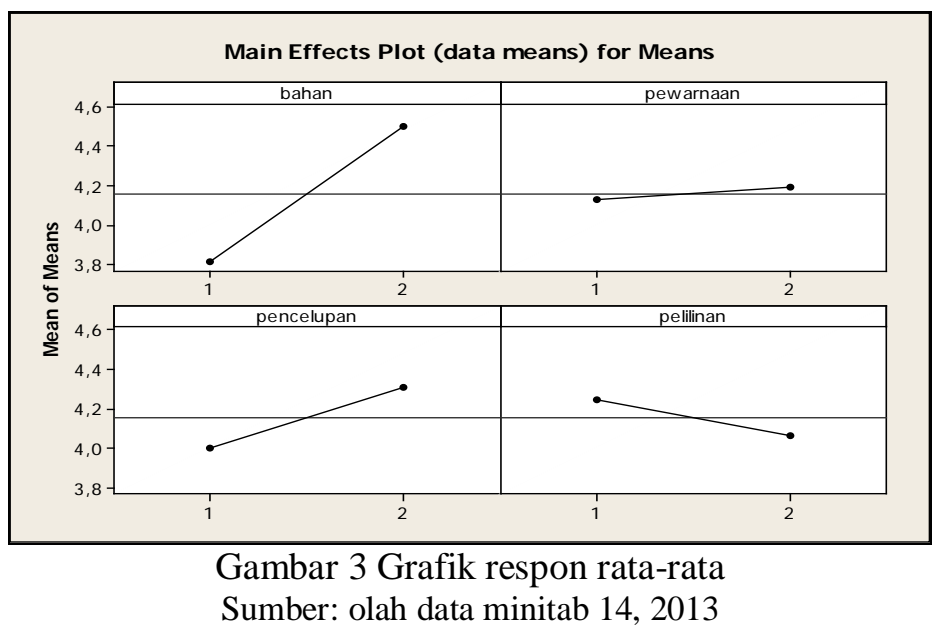

Berdasarkan gambar 3 grafik untuk respon rata-rata tiap level faktor, dapat juga dilihat bahwa faktor bahan yang mempunyai rata- rata ketahanan luntur warna terhadap gosokan kain yang lebih tinggi adalah level 2, faktor pewarnaan yang mempunyai rata-rata ketahanan luntur warna terhadap gosokan kain yang lebih tinggi adalah level 2, faktor pencelupan yang mempunyai rata-rata ketahanan luntur warna terhadap gosokan kain tertinggi adalah level 2, sedangkan faktor pelilinan yang tertinggi adalah level 1 .

Sedangkan taguchi dengan menggunakan analysis of signal to noise ratio untuk mencari faktor-faktor yang memiliki kontribusi pada pengurangan variansi suatu karakteristik kualitas (variabel respon). Karakteristik kualitas yang digunakan adalah ketahanan luntur warna terhadap gosokan kain, dimana semakin tinggi nilainya semakin baik sehingga SNR yang digunakan adalah larger the better. Dapat ditunjukkan pada tabel dibawah ini.

Tabel 14 Tabel Respon untuk nilai SNR Response Table for Signal to Noise Ratios Larger is better

\begin{tabular}{lrrrr}
\hline Level & bahan & pewarnaan & pencelupan & pelilinan \\
1 & 11,49 & 12,12 & 11,79 & 12,38 \\
2 & 12,85 & 12,22 & 12,55 & 11,96 \\
Delta & 1,36 & 0,11 & 0,76 & 0,43 \\
Rank & 1 & 4 & 2 & 3 \\
\hline
\end{tabular}

Sumber: olah data minitab 14, 2013

Berdasarkan tabel 14 dapat dilihat bahwa faktor bahan yang mempunyai nilai SNR eksperimen ketahanan luntur warna terhadap gosokan kain yang lebih tinggi adalah level 2, faktor pewarnaan yang mempunyai nilai eksperimen ketahanan luntur warna terhadap gosokan kain yang lebih tinggi adalah level 2, faktor pencelupan yang mempunyai nilai eksperimen ketahanan luntur warna terhadap gosokan kain tertinggi adalah level 2, sedangkan faktor pelilinan yang tertinggi adalah level 1. Dari tabel respon rata-rata diatas dapat juga dilihat pada gambar grafik untuk respon nilai SNR tiap level faktor 


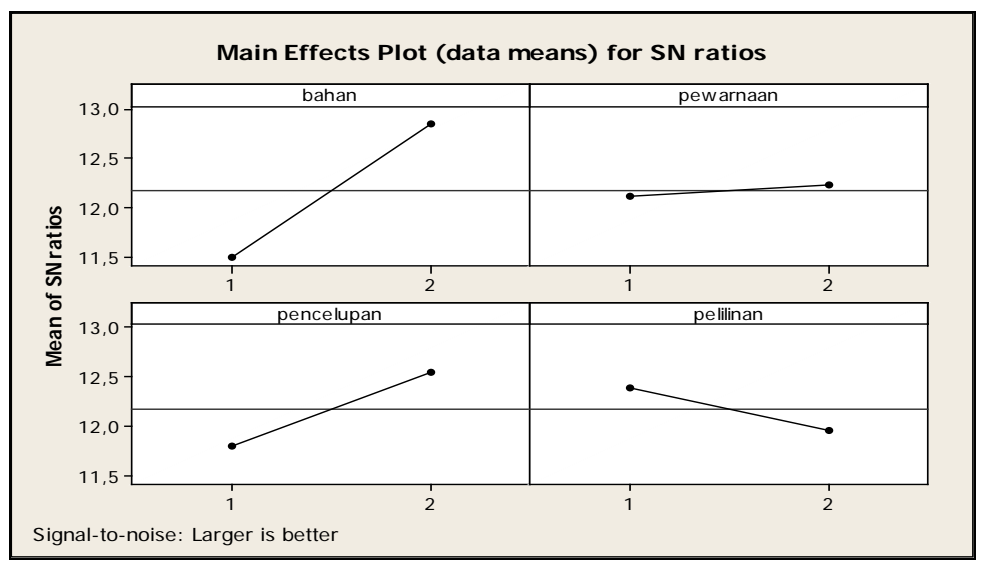

Gambar 4 Grafik untuk Respon Nilai SNR

Sumber: olah data minitab 14, 2013

Berdasarkan gambar 4 grafik untuk respon rata-rata tiap level faktor, dapat juga dilihat bahwa faktor bahan yang mempunyai rata- rata ketahanan luntur warna terhadap gosokan kain yang lebih tinggi adalah level 2, faktor pewarnaan yang mempunyai rata-rata ketahanan luntur warna terhadap gosokan kain yang lebih tinggi adalah level 2, faktor pencelupan yang mempunyai rata-rata ketahanan luntur warna terhadap gosokan kain tertinggi adalah level 2, sedangkan faktor pelilinan yang tertinggi adalah level 1 .

Dari analisis statistik terhadap nilai respon rata-rata dan SNR baik dari perhitungan tabel dan grafik memberikan hasil yang sama yaitu: faktor A (bahan) yang mempunyai rata-rata ketahanan luntur warna terhadap gosokan kain yang lebih tinggi adalah level 2, faktor B (pewarnaan) yang mempunyai rata-rata ketahanan luntur warna terhadap gosokan kain yang lebih tinggi adalah level 2, faktor C (pencelupan) yang mempunyai rata-rata ketahanan luntur warna terhadap gosokan kain yang lebih tinggi adalah level 2, dan faktor D (pelilinan) yang mempunyai rata-rata ketahanan luntur warna terhadap gosokan kain yang lebih tinggi adalah level 1.

\section{d. Menghitung Analysis Of Variance}

Analisis selanjutnya adalah menghitung Analysis of Variance (mean) dan Analysis of Variance (SNR) dari tabel respon, hasil Analysis of Variance (mean) dapat dilihat pada tabel 8 dibawah ini:

\section{Tabel 15 Analysis of Variance (mean)} Analysis of Variance for Means

\begin{tabular}{lrrrrrr}
\hline Source & DF & Seq SS & Adj SS & Adj MS & F & P \\
bahan & 1 & 0,94531 & 0,945313 & 0,945313 & 4,84 & 0,159 \\
pewarnaan & 1 & 0,00781 & 0,007813 & 0,007813 & 5,04 & 0,860 \\
pencelupan & 1 & 0,19531 & 0,195313 & 0,195313 & 6,00 & 0,423 \\
pelilinan & 1 & 0,07031 & 0,070313 & 0,070313 & 5,36 & 0,609 \\
bahan*pewarnaan & 1 & 0,00781 & 0,007812 & 0,007812 & 0,04 & 0,860 \\
Residual Error & 2 & 0,39062 & 0,390625 & 0,195312 & & \\
Total & 7 & 1,61719 & & & & \\
\hline
\end{tabular}

Sumber: olah data minitab 14, 2013

Berdasarkan tabel 16 maka dapat dilihat bahwa $\mathrm{F}$ hitung lebih besar dari $\mathrm{F}$ tabel, yaitu $\mathrm{F}_{\mathrm{A}}=4,84>\mathrm{F}_{\text {tabel }}=4,74 ; \mathrm{F}_{\mathrm{B}}=5,04>\mathrm{F}_{\text {tabel }}=4,74 ; \mathrm{F}_{\mathrm{C}}=6,00>\mathrm{F}_{\text {tabel }}=$ 4,$74 ;$ dan $F_{D}=5,36>F_{\text {tabel }}=4,74$. Ini berarti semua faktor signifikan terhadap ketahanan luntur warna pada gosokan kain. 

ini:

Untuk Analysis of Variance (SNR) dapat dilihat pada tabel 9 dibawah

Tabel 16 Analysis of Variance (SNR) Analysis of variance for $\mathrm{SN}$ ratios

\begin{tabular}{lrrrrrr}
\hline Source & DF & Seq SS & Adj SS & Adj MS & F & P \\
bahan & 1 & 3,68401 & 3,68401 & 3,68401 & 4,82 & 0,235 \\
pewarnaan & 1 & 0,02399 & 0,02399 & 0,02399 & 5,02 & 0,905 \\
pencelupan & 1 & 1,14357 & 1,14357 & 1,14357 & 4,88 & 0,448 \\
pelilinan & 1 & 0,36749 & 0,36749 & 0,36749 & 5,28 & 0,649 \\
bahan*pewarnaan & 1 & 0,09504 & 0,09504 & 0,09504 & 5,07 & 0,813 \\
Residual Error & 2 & 2,61197 & 2,61197 & 1,30598 & & \\
Total & 7 & 7,92606 & & & &
\end{tabular}

Sumber: olah data minitab 14, 2013

Berdasarkan tabel 16 maka dapat dilihat bahwa $\mathrm{F}$ hitung lebih besar dari $\mathrm{F}$ tabel, yaitu $\mathrm{F}_{\mathrm{A}}=4,82>\mathrm{F}_{\text {tabel }}=4,74 ; \mathrm{F}_{\mathrm{B}}=5,02>\mathrm{F}_{\text {tabel }}=4,74 ; \mathrm{F}_{\mathrm{C}}=4,88>\mathrm{F}_{\text {tabel }}=$ 4,74; dan $F_{D}=5,28>F_{\text {tabel }}=4,74$. Ini berarti semua faktor signifikan terhadap ketahanan luntur warna pada gosokan kain.

Dari Analysis of Variance mean dan SNR memberikan hasil yang sama yaitu F hitung lebih besar dari F tabel ini berarti bahwa semua faktor signifikan terhadap ketahanan luntur warna pada gosokan kain

\section{Pengujian Kekuatan Tarik dan Mulur Kain}

Pengujian ini dimaksudkan untuk mengetahui Kekuatan Tarik dan Mulur Kain produk batik tulis Tegal. Data pengujian Kekuatan Tarik dan Mulur Kain terlihat pada tebel 17 sebagai berikut:

Tabel 17 Hasil Eksperimen Taguchi

\begin{tabular}{|c|c|c|c|c|c|c|c|l|}
\hline \multirow{2}{*}{ NO } & \multicolumn{4}{|c|}{ FAKTOR TERKENDALI } & \multicolumn{4}{c|}{ REPLIKASI DESAIN } \\
\cline { 2 - 9 } & A & B & C & D & \multicolumn{1}{|c|}{$\mathbf{1}$} & $\mathbf{2}$ & $\mathbf{3}$ & \multicolumn{1}{|c|}{} \\
\hline 1 & 1 & 1 & 1 & 1 & 27.10 & 28.50 & 26.50 & 27.399 \\
\hline 2 & 1 & 1 & 2 & 2 & 30.899 & 28.399 & 27.399 & 23.50 \\
\hline 3 & 1 & 2 & 1 & 1 & 27.399 & 25.60 & 27.70 & 25.399 \\
\hline 4 & 1 & 2 & 2 & 2 & 29.10 & 25.10 & 28.60 & 25.799 \\
\hline 5 & 2 & 1 & 1 & 2 & 28.10 & 28.50 & 26.10 & 27.399 \\
\hline 6 & 2 & 1 & 2 & 1 & 26.399 & 27.399 & 25.60 & 25.399 \\
\hline 7 & 2 & 2 & 1 & 2 & 28.50 & 27.399 & 25.60 & 27.70 \\
\hline 8 & 2 & 2 & 2 & 1 & 29.10 & 27.399 & 25.60 & 25.399 \\
\hline
\end{tabular}


a. Uji Normalitas Data pada eksperimen taguchi

Tabel 18 Uji Normalitas Data

One-Sample Kolmogorov-Smirnov Test

\begin{tabular}{|ll|r|r|r|r|}
\hline & & Rep_des_1 & Rep_des_2 & Rep_des_3 & Rep_des_4 \\
\hline N & & 8 & 8 & 8 & 8 \\
Normal Parameters ${ }^{\mathrm{a}}{ }^{2}$ & Mean & 28.32 & 27.29 & 26.64 & 26.00 \\
& Std. Deviation & 1.413 & 1.301 & 1.140 & 1.423 \\
Most Extreme & Absolute & .167 & .284 & .194 & .212 \\
\multicolumn{1}{c|}{ Differences } & Positive & .167 & .176 & .194 & .181 \\
& Negative & -.091 & -.284 & -.181 & -.212 \\
Kolmogorov-Smirnov Z & & .471 & .804 & .548 & .601 \\
Asymp. Sig. (2-tailed) & .979 & .537 & .925 & .864 \\
\hline a. Test distribution is Normal. & & & & \\
\hline
\end{tabular}

Sumber : olah data SPSS 16, 2013

Berdasarkan perhitungan, didapat nilai $p$ pada seluruh aspek lebih besar daripada 0.05 ( $p>0.05$ ) dengan demikian semua data berdistribusi normal.

\section{b. Uji Homogenitas Data pada eksperimen taguchi}

Tabel 19 Uji homogenitas data

Test of Homogeneity of Variance

\begin{tabular}{|c|c|c|c|c|c|}
\hline & & Levene Statistic & df1 & df2 & Sig. \\
\hline \multirow[t]{4}{*}{ Replikasi_des } & Based on Mean & .108 & 3 & 28 & .955 \\
\hline & Based on Median & .101 & 3 & 28 & .959 \\
\hline & $\begin{array}{l}\text { Based on Median and with } \\
\text { adjusted df }\end{array}$ & .101 & 3 & 26.795 & .959 \\
\hline & Based on trimmed mean & .145 & 3 & 28 & .932 \\
\hline
\end{tabular}

Sumber : olah data SPSS 16, 2013

Berdasarkan perhitungan, didapat nilai $p$ lebih besar daripada 0.05 ( $p>$ 0.05 ) dengan demikian data hasil eksperiment taguchi memiliki varian yang homogen.

Setelah diketahui bahwa hasil eksperiment taguchi memiliki syarat bahwa data tersebut adalah normal dan homogen, maka langkah selanjutnya adalah menghitung berdasarkan langkah-langkah eksperiment taguchi:

c. Menghitung nilai rata-rata dan SNR pada eksperimen taguchi

Tabel 20 respon untuk nilai rata-rata Response Table for Means

\begin{tabular}{lrrrr}
\hline Level & bahan & pewarnaan & pencelupan & pelilinan \\
1 & 27,15 & 27,16 & 27,18 & 26,74 \\
2 & 26,97 & 26,96 & 26,94 & 27,38 \\
Delta & 0,18 & 0,20 & 0,24 & 0,64 \\
Rank & 4 & 3 & 2 & 1 \\
\hline
\end{tabular}

Sumber: olah data minitab 14, 2013

Berdasarkan tabel dapat dilihat bahwa faktor bahan yang mempunyai rata- rata nilai eksperimen Kekuatan Tarik dan Mulur Kain yang lebih tinggi adalah level 1, faktor pewarnaan yang mempunyai nilai eksperimen Kekuatan Tarik dan Mulur Kain yang lebih tinggi adalah level 1, faktor pencelupan yang 
mempunyai nilai eksperimen Kekuatan Tarik dan Mulur Kain terhadap gosokan kain dalah level 1, sedangkan faktor pelilinan yang tertinggi adalah level 2. Dari tabel respon rata-rata diatas dapat juga dilihat pada gambar grafik untuk respon rata-rata tiap level faktor

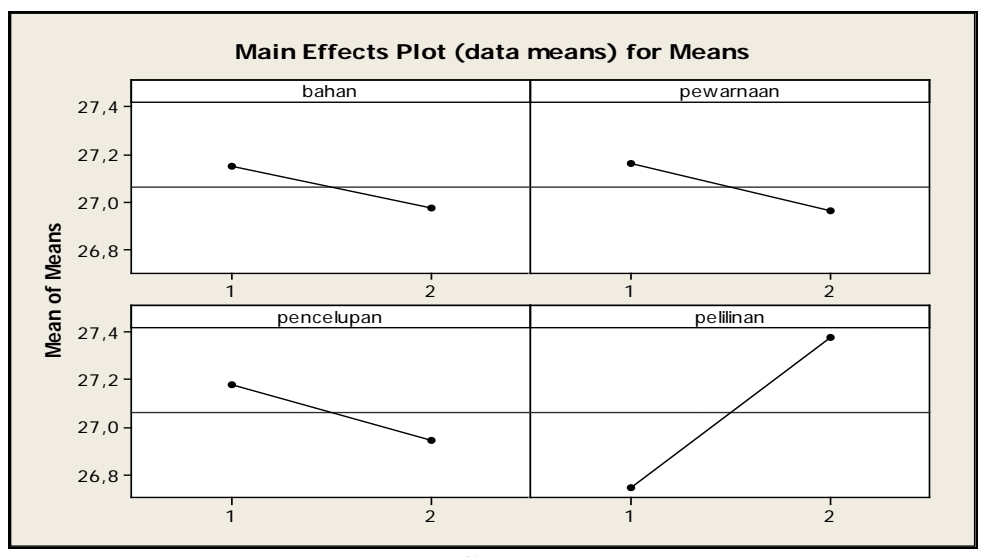

Gambar 5 Grafik respon rata-rata

Sumber: olah data minitab 14, 2013

Berdasarkan gambar 5 grafik untuk respon rata-rata tiap level faktor, dapat juga dilihat bahwa faktor bahan yang mempunyai rata- rata Kekuatan Tarik dan Mulur Kain yang lebih tinggi adalah level 1, faktor pewarnaan yang mempunyai rata-rata Kekuatan Tarik dan Mulur Kain yang lebih tinggi adalah level 1, faktor pencelupan yang mempunyai rata-rata Kekuatan Tarik dan Mulur Kain tertinggi adalah level 1 , sedangkan faktor pelilinan yang tertinggi adalah level 2.

Sedangkan taguchi dengan menggunakan analysis of signal to noise ratio untuk mencari faktor-faktor yang memiliki kontribusi pada pengurangan variansi suatu karakteristik kualitas (variabel respon). Karakteristik kualitas yang digunakan adalah Kekuatan Tarik dan Mulur Kain, dimana semakin tinggi nilainya semakin baik sehingga SNR yang digunakan adalah larger the better. Dapat ditunjukkan pada tabel dibawah ini.

Tabel 22 Tabel Respon untuk nilai SNR

Response Table for Signal to Noise Ratios Larger is better

\begin{tabular}{lrrrr}
\hline Level & bahan & pewarnaan & pencelupan & pelilinan \\
1 & 28,62 & 28,64 & 28,67 & 28,52 \\
2 & $28,6 \odot$ & 28,58 & 28,55 & 28,69 \\
Delta & 0,03 & 0,05 & 0,12 & 0,17 \\
Rank & 4 & 3 & 2 & 1 \\
\hline
\end{tabular}

Sumber: olah data minitab 14, 2013

Berdasarkan tabel 22 dapat dilihat bahwa faktor bahan yang mempunyai nilai SNR eksperimen Kekuatan Tarik dan Mulur Kain yang lebih tinggi adalah level 1, faktor pewarnaan yang mempunyai nilai eksperimen Kekuatan Tarik dan Mulur Kain yang lebih tinggi adalah level 1, faktor pencelupan yang mempunyai nilai Kekuatan Tarik dan Mulur Kain terhadap gosokan kain tertinggi adalah level 1, sedangkan faktor pelilinan yang tertinggi adalah level 2. Dari tabel respon rata-rata diatas dapat juga dilihat pada gambar 5 grafik untuk respon nilai SNR tiap level faktor 


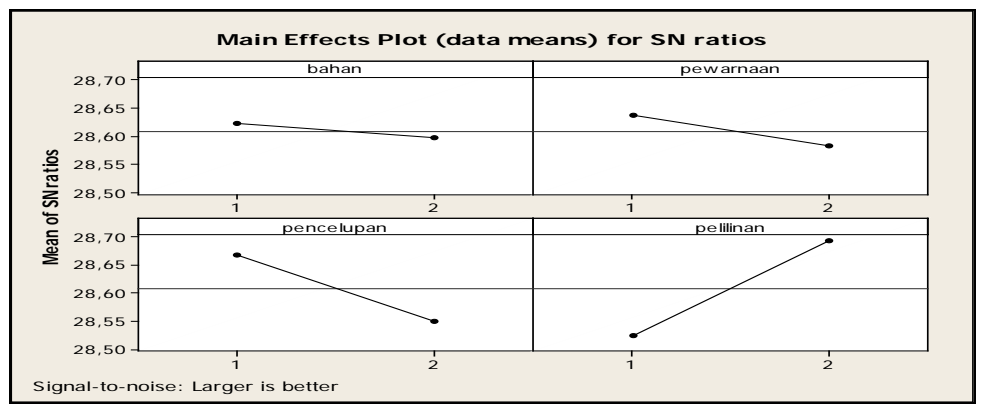

Gambar 6 Grafik untuk Respon Nilai SNR

Sumber: olah data minitab 14, 2013

Berdasarkan gambar 6 grafik untuk respon rata-rata tiap level faktor, dapat juga dilihat bahwa faktor bahan yang mempunyai rata- rata Kekuatan Tarik dan Mulur Kain terhadap gosokan kain yang lebih tinggi adalah level 2, faktor pewarnaan yang mempunyai rata-rata Kekuatan Tarik dan Mulur Kain yang lebih tinggi adalah level 2, faktor pencelupan yang mempunyai rata-rata Kekuatan Tarik dan Mulur Kain tertinggi adalah level 2, sedangkan faktor pelilinan yang tertinggi adalah level 1.

Dari analisis statistik terhadap nilai respon rata-rata dan SNR baik dari perhitungan tabel dan grafik memberikan hasil yang sama yaitu: faktor A (bahan) yang mempunyai rata-rata Kekuatan Tarik dan Mulur Kain yang lebih tinggi adalah level 1, faktor B (pewarnaan) yang mempunyai rata-rata Kekuatan Tarik dan Mulur Kain yang lebih tinggi adalah level 1, faktor C (pencelupan) yang mempunyai rata-rata Kekuatan Tarik dan Mulur Kain yang lebih tinggi adalah level 1, dan faktor D (pelilinan) yang mempunyai rata-rata Kekuatan Tarik dan Mulur Kain yang lebih tinggi adalah level 2.

Analisis selanjutnya adalah menghitung Analysis of Variance (mean) dan Analysis of Variance (SNR) dari tabel respon, hasil Analysis of Variance (mean) dapat dilihat pada tabel 8 dibawah ini:

Tabel 23 Analysis of Variance (mean) Analysis of Variance for Means

\begin{tabular}{lrrrrrr}
\hline Source & DF & Seq SS & Adj SS & Adj MS & F & P \\
bahan & 1 & 0,06125 & 0,06125 & 0,06125 & 5,48 & 0,559 \\
pewarnaan & 1 & 0,07990 & 0,07990 & 0,07990 & 5,63 & 0,510 \\
pencelupan & 1 & 0,11305 & 0,11305 & 0,11305 & 4,89 & 0,445 \\
pelilinan & 1 & 0,81313 & 0,81313 & 0,81313 & 5,42 & 0,127 \\
bahan*pewarnaan & 1 & 0,36125 & 0,36125 & 0,36125 & 4,85 & 0,233 \\
Residual Error & 2 & 0,25341 & 0,25341 & 0,12670 & & \\
Total & 7 & 1,68199 & & & & \\
\hline
\end{tabular}

Sumber: olah data minitab 14, 2013

Berdasarkan tabel 23 maka dapat dilihat bahwa $\mathrm{F}$ hitung lebih besar dari $\mathrm{F}$ tabel, yaitu $\mathrm{F}_{\mathrm{A}}=5,48>\mathrm{F}_{\text {tabel }}=4,74 ; \mathrm{F}_{\mathrm{B}}=5,63>\mathrm{F}_{\text {tabel }}=4,74 ; \mathrm{F}_{\mathrm{C}}=4,89>\mathrm{F}$ tabel $=4,74$; dan $\mathrm{F}_{\mathrm{D}}=5,42>\mathrm{F}_{\text {tabel }}=4,74$. Ini berarti semua faktor signifikan terhadap Kekuatan Tarik dan Mulur Kain.

Untuk Analysis of Variance (SNR) dapat dilihat pada tabel 9 dibawah ini: 
Tabel 24 Analysis of Variance (SNR) Analysis of Variance for SN ratios

\begin{tabular}{lrrrrrr}
\hline Source & DF & Seq SS & Adj SS & Adj MS & F & P \\
bahan & 1 & 0,001300 & 0,001300 & 0,001300 & 5,08 & 0,802 \\
pewarnaan & 1 & 0,005986 & 0,005986 & 0,005986 & 5,37 & 0,603 \\
pencelupan & 1 & 0,028486 & 0,028486 & 0,028486 & 5,78 & 0,314 \\
pelilinan & 1 & 0,058600 & 0,058600 & 0,058600 & 5,66 & 0,196 \\
bahan*pewarnaan & 1 & 0,025416 & 0,025416 & 0,025416 & 5,59 & 0,335 \\
Residual Error & 2 & 0,031998 & 0,031998 & 0,015999 & & \\
Total & 7 & 0,151786 & & & &
\end{tabular}

Sumber: olah data minitab 14, 2013

Berdasarkan tabel 24 maka dapat dilihat bahwa $\mathrm{F}$ hitung lebih besar dari $\mathrm{F}$ tabel, yaitu $\mathrm{F}_{\mathrm{A}}=5,08>\mathrm{F}_{\text {tabel }}=4,74 ; \mathrm{F}_{\mathrm{B}}=5,37>\mathrm{F}_{\text {tabel }}=4,74 ; \mathrm{F}_{\mathrm{C}}=5,78>\mathrm{F}_{\text {tabel }}$ $=4,74$; dan $F_{D}=5,66>F$ tabel $=4,74$. Ini berarti semua faktor signifikan terhadap Kekuatan Tarik dan Mulur Kain.

Dari Analysis of Variance mean dan SNR memberikan hasil yang sama yaitu $\mathrm{F}$ hitung lebih besar dari $\mathrm{F}$ tabel ini berarti bahwa semua faktor signifikan terhadap Kekuatan Tarik dan Mulur Kain

\section{Menentukan Setting level Optimal}

Sangat penting untuk menggunakan dua tahap proses optimasi dalam mengoptimalkan karakteristik kualitas, yaitu mengurangi variansi dan mengatur target dengan spesifikasi yang diinginkan. Berikut adalah tabel perbandingan pengaruh faktor dalam penentuan setting level optimal:

Tabel 25 Perbandingan Pengaruh Faktor

\begin{tabular}{|c|c|c|c|c|}
\hline Faktor & Rata-rata & SNR & Pengaruh & Gunakan \\
\hline A & $\sqrt{1}$ & $\sqrt{ } 1$ & Rata-rata dan variansi & A2 \\
\hline B & $\sqrt{2}$ & $\sqrt{2}$ & Rata-rata dan variansi & B2 \\
\hline C & $\sqrt{3}$ & $\sqrt{3}$ & Rata-rata dan variansi & C2 \\
\hline D & $\sqrt{4}$ & $\sqrt{4}$ & Rata-rata dan variansi & D2 \\
\hline
\end{tabular}

Berdasarkan tabel perbandingan diatas menunjukkan faktor tersebut penting. Angka disebelah $\sqrt{ }$ menunjukkan rangking dan dihasilkan kombinasi level faktor yaitu: A2, B2, C2, dan D2

\section{Uji Beda}

a. Uji Beda Batik tulis tegal Desain Awal dengan Batik tulis tegal Hasil Rancangan pada Ketahanan luntur warna terhadap sabun

Hasil uji Normalitas keseluruhan data berdistribusi normal, maka analisis yang digunakan adalah uji compare mean yaitu dengan menggunakan uji $\mathrm{t}$ berpasangan (Paired sample T-Test). Hasil uji t untuk subjek ditunjukkan pada tabel 26

Tabel 26 Rata-rata, standard deviasi dan uji t antara Desain Sebelum Rancangan dan Desain Sesudah Rancangan

\begin{tabular}{|c|c|c|c|c|}
\hline Variabel & Rata-rata & Standard deviasi & t hitung & $\boldsymbol{P}$ \\
\hline Sebelum eksperiment & 4.1111 & .33333 & \multirow{2}{*}{-3.500} & \multirow{2}{*}{.008} \\
\hline Sesudah eksperiment & 4.8889 & .33333 & & \\
\hline
\end{tabular}


Tabel 26 menyatakan bahwa sebelum dan sesudah eksperiment pada sampel didapat nilai probabilitas sebesar 0,008 $(\mathrm{p}<0,05$ ). Dengan demikian dapat disimpulkan bahwa terdapat peningkatan kualitas yang bermakna antara variabel pada desain batik awal dan desain batik hasil rancangan. Beda rerata sebelum dan sesudah eksperimen adalah sebesar 0,777 atau terjadi peningkatan sebesar $8 \%$.

b. Uji Beda Batik tulis tegal Desain Awal dengan Batik tulis tegal Hasil Rancangan pada Kekuatan Tarik (Kg)

Hasil uji Normalitas keseluruhan data berdistribusi normal, maka analisis yang digunakan adalah uji compare mean yaitu dengan menggunakan uji t berpasangan (Paired sample T-Test). Hasil uji t untuk subjek ditunjukkan pada tabel 27

Tabel 27 Rata-rata, standard deviasi dan uji t antara Desain Sebelum Rancangan dan Desain Sesudah Rancangan

\begin{tabular}{|c|c|c|c|c|}
\hline Variabel & Rata-rata & Standard deviasi & t hitung & $\boldsymbol{P}$ \\
\hline Sebelum eksperiment & 25.0222 & .88851 & \multirow{2}{*}{-5.303} & \multirow{2}{*}{.001} \\
\hline Sesudah eksperiment & 27.6773 & 1.11152 & \\
\hline
\end{tabular}

Tabel 27 menyatakan bahwa sebelum dan sesudah eksperiment pada sampel didapat nilai probabilitas sebesar 0,001 ( $\mathrm{p}<0,05$ ). Dengan demikian dapat disimpulkan bahwa terdapat peningkatan kualitas yang bermakna antara variabel pada desain batik awal dan desain batik hasil rancangan. Beda rerata sebelum dan sesudah eksperimen adalah sebesar 2,6551 atau terjadi peningkatan sebesar 5,03 \%.

c. Uji Beda Batik tulis tegal Desain Awal dengan Batik tulis tegal Hasil Rancangan pada Ketahanan Luntur Warna terhadap Gosokan Kain (kering)

Hasil uji Normalitas keseluruhan data berdistribusi normal, maka analisis yang digunakan adalah uji compare mean yaitu dengan menggunakan uji t berpasangan (Paired sample T-Test). Hasil uji t untuk subjek ditunjukkan pada tabel 28

Tabel 28 Rata-rata, standard deviasi dan uji t antara Desain Sebelum Rancangan dan Desain Sesudah Rancangan

\begin{tabular}{|c|c|c|c|c|}
\hline Variabel & Rata-rata & Standard deviasi & t hitung & $\boldsymbol{P}$ \\
\hline Sebelum eksperiment & 3.4444 & .52705 & \multirow{2}{*}{-8.22} & \multirow{2}{*}{.000} \\
\hline Sesudah eksperiment & 4.8889 & .33333 & \\
\hline
\end{tabular}

Tabel 28 menyatakan bahwa sebelum dan sesudah eksperiment pada sampel didapat nilai probabilitas sebesar 0,000 ( $\mathrm{p}<0,05$ ). Dengan demikian dapat disimpulkan bahwa terdapat peningkatan kualitas yang bermakna antara variabel pada desain batik awal dan desain batik hasil rancangan. Beda rerata sebelum dan sesudah eksperimen adalah sebesar 1,4449 atau terjadi peningkatan sebesar $17,33 \%$.

\section{KESIMPULAN}

Dari penelitian ini dapat diambil kesimpulan sebagai berikut:

1. Faktor -faktor yang berpengaruh pada hasil desain produk batik tulis Tegal adalah bahan kain batik, pewarnaan, pencelupan dan pelilinan

2. Dari analisis of variance mean dan SNR memberikan hasil yaitu $\mathrm{F}$ hitung lebih besar dari $\mathrm{F}$ tabel ini berarti bahwa semua faktor signifikan terhadap Ketahanan Luntur 
Warna terhadap Sabun, Ketahanan Luntur Warna terhadap Gosokan Kain, dan Kekuatan Tarik dan Mulur Kain.

3. Setting level optimal dari tingkat kualitas hasil desain sebagai dasar peningkatan kualitas produk batik tulis Tegal adalah pada bahan kain batik menggunakan mori primissima kupu, pewarnaan dengan warna naftol, pencelupan selama 50 menit dan pelilinan dengan suhu $70^{\circ} \mathrm{C}$.

4. Peningkatan kualitas batik tulis tegal dari pengujian ketahanan luntur warna terhadap sabun, kekuatan tarik, dan ketahanan luntur warna terhadap gosokan kering masingmasing adalah sebesar 8\%, 5,03\% dan 17,33\% dengan rata-rata peningkatan kualitas sebesar $10,12 \%$

\section{DAFTAR PUSTAKA}

[1] Indrojarwo, Baroto. 2010. "Development of Indonesia New Batik Design by Exploration and Exploitation of Recent Context" jurnal penelitian desain produk industry FTSP ITS.

[2] Hasanudin. 2001. Batik Pesisiran; Melacak Pengaruh Etos Dagang Santri pada Ragam Hias Batik, Bandung, Kiblat Buku Utama.

[3] Raharjo, Budi. 2006. Kerajinan Batik Tulis Tengah Sawah Desa Wiyoro Kecamatan Ngadirojo Kabupaten Pacitan. Jurusan Pendidikan Seni dan Desain Fakultas Sastra Universitas Negeri Malang.

[4] Ross, Philip J. 1996. Taguchi Tecnique for Quality Engineering Second Edition. Mc Graw Hill Book Company Inc. Singapore 